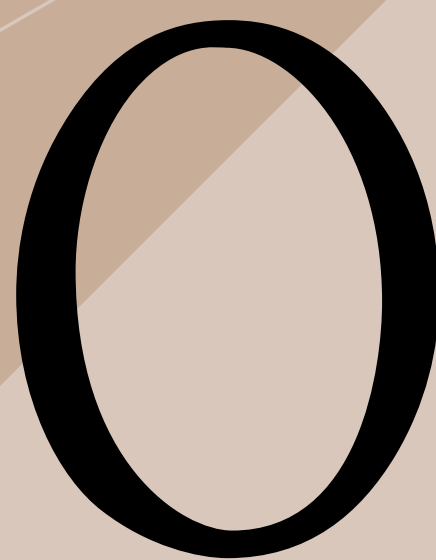

Laboratório de Estudos sobre a Intolerância (LEI), núcleo de estudos e documentação ligado à Faculdade de Filosofia, Letras e Ciências Humanas da Universidade de São Paulo, tem oferecido enorme contribuição aos estudos acadêmicos com grande alcance social. Sob iniciativa de Anita Novinsky, mestra de tantos historiadores brasileiros, vem estimulando uma produção historiográfica original de excelente nível, sem prejuízo de sua proposta explicitamente engajada. Uma proposta, no caso, voltada para o estudo crítico de duas grandes vertentes de intolerância na história dos povos, sobretudo na Europa e nas Américas: a intolerância étnica e a intolerância política.

A maioria das publicações do LEI estão sendo produzidas pelaAssociação Editorial Humanitas em parceria com a Fapesp. Em novembro de 2002, data de fundação do LEI, foi lançado o primeiro título da coleção Ensaios sobre a Intolerância: Inquisição, Marranismo e Anti-semitismo, livro em homenagem a Anita Novinsky, organizado por Lina Gorenstein e Maria Luiza Tucci 


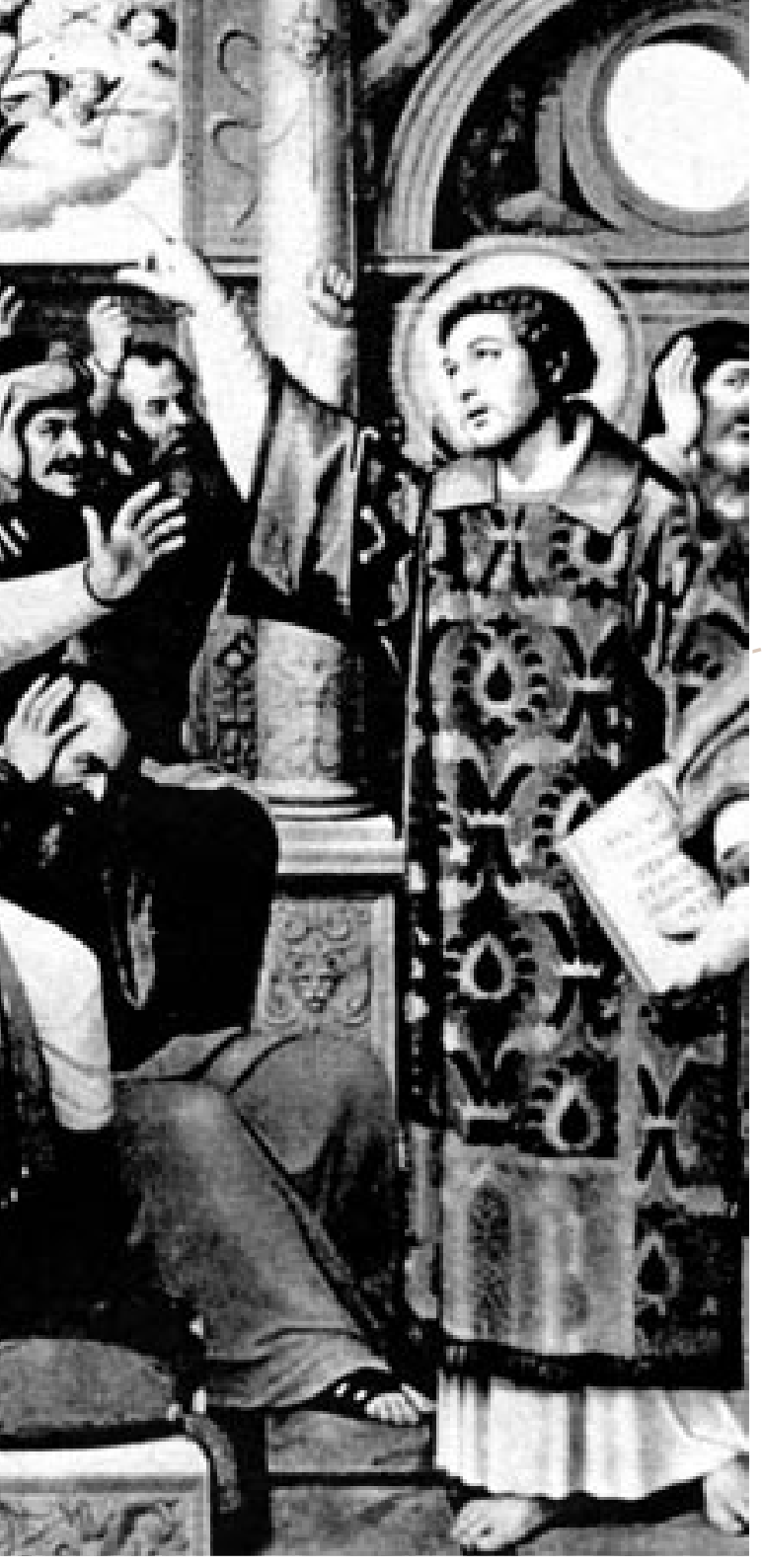

Carneiro. Essa coletânea, relançada no ano de 2005 pela Humanitas, reúne ensaios de ex-alunos e historiadores dedicados há décadas aos estudos inquisitoriais. O livro tem por foco o estudo de cristãos-novos e judaizantes que, entre os séculos XVI e XVIII, viveram sob a permanente ameaça do Santo Ofício português, seja no reino, seja no ultramar. Mas incursiona também no domínio de outras "heresias", muito menos graves do que o judaísmo, aos olhos dos inquisidores, mas nem por isso irrelevantes. Luiz Mott apresenta "Filhos de Abraão \& de Sodoma”, estudo original sobre os cristãos-novos acusados de praticar, não o judaísmo (ou não somente), mas o pecado nefando. Laura de Mello e Souza revisita o calundu, palavra que, no século XVIII, aludia genericamente a uma plêiade de ritos de origem africana demonizados pela Inquisição. Lana Lage da Gama Lima trata do Recolhimento das Macaúbas, nas Minas setecentistas, atenta aos padres solicitantes, isto é, os que se aproveitavam da privacidade da confissão para seduzir as mulheres ali recolhidas em virtude. Crimes menores, repito, mas ainda assim perseguidos, cujos processos permitem iluminar faces importantíssimas do cotidiano colonial, reconstruindo a tessitura complexa das religiosidades e moralidades de nosso passado.

Em 2004 foi lançado o livro Intolerância e Resistência, de Zilda Gricoli Iokoi, professora de História Contemporânea da USP, que tem como tema os judeus comunistas de origem polonesa no Brasil entre 1935 e 1975. Em 2005, um outro livro acrescenta conhecimentos aos estudos de comunidades étnicas no Brasil do século XX, O Germe da Revolução, de Erick Reis Godliausskas Zen, resultado de uma pesquisa em nível de iniciação científica sobre os lituanos que emigraram para o Brasil e caíram, muitos deles, sob a vigilância do Departamento de Ordem Política e Social (Deops/SP). Esse estudo é produto do Projeto Integrado Arquivo do Estado/USP (Proin), projeto temático coordenado por Maria Luiza Tucci Carneiro, organizadora da Série Inventários Deops. Até então, outros doze títulos foram editados pela Imprensa Oficial do Estado em parceria com o Arquivo do Estado. O autor ressalta que, entre 1920 e 1950 , os
Ao lado,

detalhe da

Fonte da Graça

e o Triunfo da

Igreja sobre

a Sinagoga

da Escola dos

Irmãos Van

Eycky

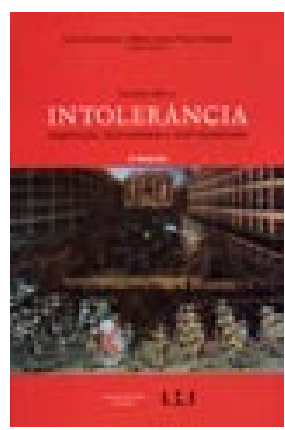

Ensaios sobre a Intolerância: Inquisicão, Marranismo e Antisemitismo, de Lina Gorenstein e Maria Luiza Tucci Carneiro (orgs.), São Paulo, Humanitas/LEI, 2005, 442 pp.

\section{RONALDO VAINFAS}

é professor de História Moderna na Universidade Federal Fluminense e membro da Companhia das Índias - Núcleo de Estudos Ibéricos e Coloniais na Época Moderna/UFF/ Pronex. 
lituanos eram intensamente vigiados como comunistas, principalmente aqueles de origem judaica.

Nesse mesmo ano de 2004, o LEI inaugurou a coleção Testemunhos, idealizada por Tucci Carneiro, que nos ofereceu o precioso livro de Sabina Kustin, A Vida e a Luta de uma Sobrevivente do Holocausto, mais um depoimento sobre a ação genocida perpetrada pelo III Reich alemão. Assunto sempre bem-vindo pelo serviço à perpetuação da memória dessa tragédia única na história do Ocidente.

Mas a coleção que ordena mais sistematicamente os estudos produzidos pelos pesquisadores do LEI intitula-se Histórias da Intolerância, organizada por Anita Novinsky, Lina Gorenstein e Tucci Carneiro. A proposta é de reunir dissertações e teses defendidas na USP nas últimas décadas, algumas antigas, outras recentíssimas, que têm como fio condutor a ação de dois reconhecidos aparatos de repressão: o Tribunal do Santo Ofício da Inquisição Ibérica e o Deops/SP, o braço estadual da polícia política do Estado republicano (1924-83). As organizadoras da série deixam claro que tais pesquisas "só se fizeram possíveis após a abertura dos arquivos inquisitoriais, policiais e diplomáticos até então sob a guarda das respectivas instituições, abrindo um novo capítulo na história do Brasil, divulgando práticas políticas repressivas e totalitárias". Isso vale sobretudo para os arquivos do regime militar brasileiro, em especial os que guardavam documentos da repressão política.

É sobre tais arquivos policiais ou judiciários que se debruçam três excelentes livros da coleção. Regina Célia Pedroso é autora de Estado Autoritário e Ideologia Policial, prefaciado por Dalmo Dallari, estudo sobre discursos e práticas policiais no Brasil republicano, especialmente em São Paulo, desde o início do século $\mathrm{XX}$ até cerca de 1940 . O foco da tese volta-se para a construção do conceito de "polícia política”, valendo destacar o capítulo final, mais ensaístico, dedicado às perspectivas atuais. Como diz a autora, “o que diferenciou a atuação repressiva durante a ditadura militar dos governos das primeiras décadas do século $\mathrm{XX}$ foi que a ditadura utilizou o Exército como principal força repressiva, enquanto o Deops serviu de coadjuvante no cenário político-repressivo, invertendo a preponderância que a polícia teve ao longo das primeiras décadas[...]" (p. 148). Maria Luiza Tucci Carneiro, orientadora do trabalho, diz bem, ao apresentar o livro, quando afirma que o livro mostra "que a crise institucional pela qual passa o aparato de Estado no Brasil não é recente".

João Henrique Botteri Negrão comparece na coleção com Selvagens e Incendiários: o Discurso Anticomunista do Governo Vargas e as Imagens da Guerra Civil Espanhola. Pesquisa muito original, baseada em fontes do Itamaraty, com rico material em anexo, comprovando, sem dúvida, a atenção dedicada pelo governo Vargas, antes mesmo do Estado Novo, à ação soviética no mundo, e os perigos que daí poderiam advir. No mesmo campo temático, Ismara Izepe de Souza é autora de Solidariedade Internacional, livro sobre o papel da comunidade espanhola residente em São Paulo em face da Guerra Civil que flagelou a Espanha a partir de 1936. Apoiada em arquivos do Fundo Dops, bem como na documentação do Ministério das Relações Exteriores, a autora dá contribuição inédita, iluminando a solidariedade de muitos espanhóis do Brasil ao governo republicano da Espanha, sem ocultar os conflitos de opinião que a guerra causou no seio da comunidade de imigrantes.

Outro livro de grande interesse, embora menos ancorado que os anteriores nos arquivos policiais, é o de Rogério Dezem, Matizes do Amarelo, pesquisa sobre o imaginário construído no Brasil acerca dos orientais, sobretudo os japoneses, entre 1878 e 1908 . Um dos pontos altos do livro encontra-se no capítulo "Teatro das Raças", que traça um painel do antiniponismo em vários países latino-americanos e nos Estados Unidos. O autor procura mostrar a gênese, ainda no século XIX, de um discurso antinipônico no Brasil que alcançaria o auge nos anos 1930-40, quando os japoneses seriam transformados "em cruéis 
espiões representantes de uma raça frígida, fanática e traiçoeira" (p. 293).

De todo modo, se as fontes diplomáticas e policiais que dão base a esses livros só recentemente foram disponibilizadas para os historiadores, isso não vale para a documentação inquisitorial que, desde o século XIX, foi transferida para o Arquivo Nacional da Torre do Tombo, em Lisboa, após a Revolução Liberal que pôs fim ao Antigo Regime português.

Estava a documentação inquisitorial à disposição de nossos historiadores desde os anos 1830, no Tombo português, e ali esteve Francisco Adolpho de Varnhagen, no meado do Oitocentos, organizando, a partir das listas de autos-de-fé, rol precioso de réus, que chamou de "brasileiros", penitenciados pelo Santo Ofício entre 1711 e 1767 , texto publicado na Revista do Instituto Histórico e Geográfico Brasileiro. Ali esteve mestre Capistrano de Abreu, no início do século XX, transcrevendo os livros de confissões e denúncias da Bahia na Primeira Visitação do Santo Ofício ao Brasil - um verdadeiro "mapa da mina" para os futuros historiadores brasileiros.

Paulo Prado, o autor do polêmico $R e$ trato do Brasil e verdadeiro mecenas de Capistrano em suas pesquisas, foi quem publicou os primeiros livros das visitações, nas décadas de 1920-30, e por essa razão é justamente lembrado pelas organizadoras da coleção. Estava convencido de que publicar documentos sobre a Inquisição era essencial "para melhor conhecer o Brasil".

Varnhagen, Capistrano, Paulo Prado, eis alguns raros exemplos dos que, no remoto passado de nossa historiografia, enxergaram a importância das fontes inquisitoriais para nossa história. O espantosoé que foi preciso esperar muitas décadas para que, no âmbito universitário, os pesquisadores se interessassem pelo arquivo inquisitorial, seja para estudar a história da repressão no Brasil, seja para estudar grupos ou indivíduos cuja trajetória foi registrada, para azar deles, nos papéis inquisitoriais. Na altura dos anos 1960 ou 1970, raríssimos eram os historiadores brasileiros preocupados com essa área de estudos, caso de destacar outra vez Anita Novinsky, cujo Cristãos-novos na Bahia, publicado em 1972, até hoje é livro de referência nesse campo. Mas não se poderia cometer a injustiça de omitir o nome do grande historiador pernambucano José Antônio Gonsalves de Mello que, fora do âmbito universitário, publicou o valioso Gente da Nação-Cristãos-novos e Judeus em Pernambuco, reeditado em 1996, obra em vários aspectos pioneira, em particular sobre o papel dos judeus portugueses durante a ocupação holandesa do Nordeste, no século XVII.

Nãoé, porém, minha intenção, fazer um balanço exaustivo dos que outrora incursionaram nas fontes inquisitoriais relativas ao Brasil, senão frisar a raridade deles. Eram pouquíssimos, há uns trinta anos, mas foram crescendo em escala geométrica a partir dos anos 1980, sobretudo na década de 1990. Cada vez mais passaram a ser defendidas teses e dissertações na USP, é claro, mas também na Universidade Federal Fluminense e, em menor escala, na Unicamp, na Universidade Federal da Bahia, na Universidade Federal de Pernambuco, tratando da repressão inquisitorial ou da vida cotidiana da colônia com base nas fontes inquisitoriais. A geração de pesquisadores cresceu a tal ponto que, atualmente, alunos de ex-alunos dos primeiros orientandos da professora Novinsky se dedicam a tais estudos, inclusive em monografias de graduação. Se considerarmos que Anita Novinsky foi a matriarca, por assim dizer, dos estudos universitários sobre a Inquisição no Brasil, poderá ela se orgulhar de ter muitos filhos, netos, bisnetos e trisnetos.

Quero crer que o avanço dos estudos sobre a Inquisição ou baseados na documentação do Santo Ofício resulta, em boa medida, do arejamento dos cursos de pós-graduação em história, que, por sinal, salvo no caso da USP, começaram a ser implantados no Brasil, como “programas”, a partir de 1971 - paradoxalmente nos "anos de chumbo" de nossa história recente. Seja como for, a partir dos anos 1980, a abertura política promovida pelos mesmos militares que criaram o regime contribuiu para libertar os cursos de história da hegemonia que o marxismo 
mais ortodoxo exercia neles - os quais, bem ou mal, eram nichos de resistência à ditadura. Deixando de ser guetos de resistência ideologicamente patrulhados, os cursos de história passaram a discutir outros temas e adotar outros referenciais para pensar a história, mormente os inseridos na história das mentalidades francesa ou na chamada história cultural.

Sem dúvida que esse processo irrigou a pós-graduação, e questões ligadas aos sentimentos, às religiosidades, às individualidades, à vida cotidiana, às sexualidades passaram a ser cada vez mais freqüentadas, ultrapassando-se, felizmente, a era das teses "economicistas" e/ou obcecadas em reduzir tudo à "luta de classes". Outras dimensões da história passaram a interessar aos pesquisadores, outras lutas, inclusive conflitos religiosos e dilemas identitários, estudados na longa duração. É absolutamente seguro que as fontes inquisitoriais constituem acervo dos mais privilegiados para desvendar esses domínios da história até então ocultos ou impossíveis de perceber nas fontes mais convencionais sobre nosso período colonial.

É nessa linha que se inserem os trabalhos sobre a Inquisição incluídos na coleção Histórias da Intolerância. Antes de tudo, o estudo clássico de Luiz Nazário, Autos-deFécomo Espetáculos de Massa, que custou a ser publicado, livro polêmico que procura demonstrar que os sistemas totalitários do século XX devem seus métodos de vigilância, propaganda e repressão ao modelo da Inquisição ibérica. Luiz Nazário faz verdadeira exegese do espetáculo público do auto-de-fé onde, à vista da multidão, desfilavam os condenados às variadas penas que o tribunal impunha aos hereges. Saíam em fileiras, organizados por vezes em alas, como num desfile festivo, agrupados conforme o tipo de delito e/ou sentenças a que estavam condenados. Não raro vinham acompanhados de "Familiares do Santo Ofício" - agentes especiais incumbidos de prender e seqüestrar bens dos suspeitos, além de outras funções, como essa de monitorar os passos dos penitenciados no espetáculo público. Vinham os réus vestidos com hábitos ou trajes adequados a seus erros e/ou indicativos da pena, sendo muitas vezes obrigados, em sentença, a continuar portando o traje infamante por determinado tempo-o que lhes custava caro, no mínimo a repugnância da população.

No auto-de-fé ouviam todos o sermão de um pregador designado ad hoc, que se esmerava em declarar o bem que o Santo Ofício prestava a todos e certamente a Deus, ao descobrir e penitenciar aqueles que, por suas condutas ou crenças heréticas, contaminavam toda a sociedade, merecendo corrigenda grave ou, mesmo, no limite, a pena capital. Feito o sermão, ouviam todos a sentença, cada um a sua, e ora a multidão exultava, jogava pedras e injuriava os condenados, ora, alguns dentre eles, lastimava o destino reservado a parentes, amigos ou amantes. O que as fontes inquisitoriais permitem perceber ou presumir, o grande José Saramago descreveu em cores vivas no seu Memorial do Convento, romance ambientando no Portugal de inícios do século XVIII, durante o reinado de D. João $\mathrm{V}$, tempo em que o Santo Ofício português alcançou o apogeu.

A cena final desses festivais espetaculares era a execução dos condenados à fogueira, ritual que celebrizou a Inquisição desde sua existência aos dias atuais. É verdade que, técnica e juridicamente falando, não era a Inquisição que exarava, nas sentenças, a pena da fogueira dos que a ela estavam condenados, sendo, como era, um tribunal religioso. $\mathrm{Na}$ fórmula-padrão, quando o Santo Ofício considerava o réu impenitente ou negativo, fito ou dissimulado, revogante, dogmatista e incorrigível, "era relaxado à justiça secular”, à qual rogava que se houvesse com o réu "benigna e piedosamente" e não procedesse à "pena de morte, nem efusão de sangue”. Em teoria, a cúria secular deveria analisar o processo. Na prática, nenhum desembargador tinha acesso aos autos, depositado nos cofres secretos do tribunal de fé, de sorte que "relaxar ao braço secular" significava entregar o condenado a um oficial da justiça real para conduzi-lo ao cadafalso. Todos sabiam disso: o rei, os inquisidores, os condenados, a multidão 
presente à cerimônia. Tratava-se de um ritual barroco que terminava na fogueira.

Luiz Nazário apresenta excelente estudo sobre a "teologia da cremação", mostrando que, não obstante a Inquisição não verbalizasse a pena de morte na fogueira, estava ela bem ancorada na teologia cristã. São Tomás de Aquino, o “Anjo das Escolas”, escrevera, na Suma Teológica do século XIII: “[ [...] os hereges merecem não somente ser excluídos da Igreja pela excomunhão, como ainda retirados do mundo pela morte". Antes dele, Santo Agostinho dizia que "todo herético é aliado do diabo, e de seus anjos, no incêndio do fogo eterno". E ninguém menos que o próprio Cristo dissera, segundo o Evangelho de São João, capítulo XV, versículo 6: “Se alguém não permanece em mim, é jogado fora como o sarnento, e ele seca e o jogam no fogo: e ele queima". Metáfora do Cristo, poder-se-ia dizer, com alguma razão. Mas a Inquisição tomou ipsis verbis a ignis crematio, embora preferisse "relaxar à cúria secular" seus condenados à morte, fiel a seu lema: "misericórdia e justiça".

Antecipava a Inquisição os métodos de propaganda e a política de extermínio do nazismo? A comparação é pertinente, tentadora. É mesmo inevitável, se lembrarmos que os alvos preferenciais das perseguições eram, no caso inquisitorial, os descendentes de judeus - os cristãos-novos - e noutro caso, os judeus propriamente ditos. Deixemos, porém, essa discussão para mais adiante, pois se insere numa problemática mais ampla da intolerância que retomarei no devido momento.

AInquisição contra as Mulheres éolivro de Lina Gorenstein incluído na coleção. Autora de primeira linha, já premiada, em 1994, com sua dissertação de mestrado Heréticos e Impuros no concurso carioca de monografias da Secretaria Municipal de Cultura do Rio de Janeiro. É livro muito importante sobre os cristãos-novos do Rio de Janeiro na primeira metade do século XVIII, suas famílias, ocupações, idéias e, sobretudo, o destino trágico que a muitos atingiu nos cárceres do Santo Ofício. Em seu novo livro, originalmente tese de doutorado, Lina Gorenstein mantém o cenário
- Rio de Janeiro colonial -, mas verticaliza o foco, dedicando-se a estudar as mulheres cristãs-novas.

Tema fascinante, que combina a abordagem histórica do anti-semitismo com uma perspectiva de gênero. E se trata de uma opção estratégica para o exame do judaísmo clandestino praticado por algumas famílias de cristãos-novos portugueses entre os séculos XVI e XVIII. Isso pela simples razão - na verdade, muito complexa - de que, após a conversão forçada dos judeus decretada por D. Manuel, em 1496, o mundo sefardita lusitano se viu abruptamente amputado de sinagogas e livros - confiscados pelo rei -, fechando-se o caminho para a renovação da tradição eminentemente letrada do judaísmo. Uma tradição, vale dizer, tremendamente misógina, pois reservava aos homens os papéis diretamente ligados à religião e ao governo da comunidade - rabinato, paranassim, etc. Nas primeiras décadas da conversão, como não havia Inquisição, pôde florescer em Portugal um judaísmo mais ou menos aberto, embora oficialmente proibido, com rabinos atuantes, livros escondidos, sinagogas improvisadas. Após 1536, com a instalação do tribunal, o judaísmo recuou para casa, ao mesmo tempo em que o desaparecimento da vida sinagogal impediu a renovação das gerações masculinas no campo religioso.

Eis o cenário para a ascensão das mulheres na conservação do judaísmo, na medida do possível, elas que, no tempo em que sua religião era permitida, desempenhavam importante função na gerência dos ritos domésticos da comunidade: a preparação do shabbat, a organização das festas judaicas, como o Purim ou o Pessah, o preparo dos alimentos conforme as tradições judaicas, a observância dos ritos fúnebres, a exemplo doesvaziamento dos vasos d'água falecendo alguém da casa, etc. Aeducação dos filhos e filhas. Transmissoras da tradição no tempo do judaísmo livre, as mulheres se tornariam as "transmissoras da heresia" por excelência no tempo das perseguições. Numa sociedade sem sinagogas, nem rabinos, sem Torah, nem Talmud, as mulheres tenderam a protagonizar muitas "esnogas" que se faziam 
em Portugal, no Brasil ou no vasto ultramar português. Mulheres-rabi: eis o que muitas se tornaram com o passar dos séculos.

Lina Gorenstein esgota o tema estudando as mulheres do Rio de Janeiro nos séculos XVII e XVIII, quando já ia longe o tempo das sinagogas, e por isso não hesita em dizer que:

“[...] os cristãos-novos estavam isolados do judaísmo bíblico e rabínico e imersos em um mundo cristão; sua crença sofrera alterações profundas, e uma geração após a conversão, a maioria dos conversos tornara-se mais cristãos do que judeus. Mesmo entre os que escolheram manter o judaísmo, tinham que ser ao mesmo tempo católicos praticantes; não tinham livros judaicos, ninguém para instruir os filhos no hebraico, sem as tardes de sábado para o estudo e debate; não era um judaísmo nem profundo, nem ortodoxo; provavelmente era uma transmissão oral de conhecimento daqueles que lembravam melhor as tradições judaicas" (p. 322).

Por tudo isso, as mulheres jogaram papel fundamental nesse criptojudaísmo que a Inquisição perseguiu, e não por acaso passaram a figurar em escala crescente, à medida que passavam os séculos, entre os réus penitenciados na Inquisição pelo “crime de judaísmo". Vale recorrer aos números relativos ao Brasil colonial à guisa de ilustração: dos 778 homens presos pela Inquisição desde o século XVI, cerca de $41 \%$ oforam por práticas judaicas, enquanto, das 298 mulheres, 74,5\% o foram pela mesma causa. Inúmeras considerações poderiam ser feitas acerca desse indicador, mas pelo menos uma merece ser repetida: as mulheres passaram a ser protagonistas na história do criptojudaísmo ibérico.

Mas, como bem demonstra Gorenstein, tratava-se de um judaísmo acanhado, ritual, epidérmico. Todas as processadas, embora cedo ou tarde confessassem sua adesão à Lei de Moisés e a prática de diversos ritos, estavam já nessa altura muito aculturadas. Raras confessaram a crença em um Deus único ou a recusa total da Santíssima Trindade. Poucas ousaram dizer que o Messias ainda era esperado e que Jesus não era Filho de Deus - crenças freqüentemente admitidas por cristãos-novos no século XVII, por exemplo - embora algumas dissessem que Cristo era um "grande santo", mas não era Deus, nem o Messias prometido nas Escrituras. Graus variados de sincretismo era o que prevalecia na crença dessas mulheres. Mas pulsava, ao menos no caso das processadas que o estudo contempla, salvo exceções, a crença íntima de que só havia salvação na Lei de Moisés.

Aconclusão da autora, muito ponderada, não temilusões a respeito do criptojudaísmo feminino colonial: “[...] as cristãs-novas foram mártires da história judaica, não como judias que foram sacrificadas por manter sua religião; mártires da história judaica porque fizeram parte daqueles que foram vítimas do anti-semitismo no decorrer dos séculos" (p. 420).

Anti-semitismo na Universidade de Coimbra, de Carlos Eduardo Calaça, é o terceiro livro da linha inquisitorial incluso na coleção. É obra que se debruça sobre a face menos conhecida da história dos cristãos-novos: a busca de ascensão social, a integração na sociedade inclusiva, sendo a Universidade de Coimbra o templo da neo-escolástica naquela época. O livro nos mostra como o grupo de cristãos-novos residentes no Rio de Janeiro, entre 1600 e 1730, conseguiu atropelar os estatutos de limpeza de sangue, alcançando a universidade. Beneficiados, talvez, pelo progressivo afrouxamento das restrições às "nódoas de sangue", como se dizia à época, no tempo de D. João IV (1640-56), tempo de Vieira, com sua "defesa dos judeus", malgrado a Inquisição. Tempo em que muitos mercadores cristãos-novos lograram também nobilitar-se pelo hábito de Cavaleiro da Ordem de Cristo, que lhes fora vedado por muito tempo, e sê-lo-ia outra vez no reinado de D. João V (1706-50).

As estratégias de ascensão social ficam visíveis nesse processo, as redes clientelares, o poder do dinheiro. Mas ficam igualmente claras as animosidades contra os cristãos-novos letrados, bem como, por outro lado, os conflitos identitários desses 
homens. Alguns dos réus examinados por Calaça fariam jus ao que Antônio José da Silva, conterrâneo e contemporâneo deles, pôs na boca de um de seus personagens: "se é culpa o não ter culpa, eu culpa tenho". Alguns pareciam ter a culpa de se declararem inocentes. Outros, a culpa de terem alguma culpa, se não por esposarem fé judaica mais profunda, culpa pela "fé da lembrança”, como diria Nathan Wachtel no seu magnífico livro de igual título.

A coleção Histórias da Intolerância oferece contribuição inestimável à historiografia brasileira e estimula um aggiornamento das consciências quanto a conflitos e tensões sobremodo complexas que afligem o mundo contemporâneo. Tensões de hoje que vêm de longe e não se resumem, é óbvio, à luta de classes. A coleção sugere, com nitidez, o caráter multifacetado de contradições que marcam a história das sociedades, bem como a dos indivíduos, onde aspectos sociais, econômicos, religiosos, raciais, afetivos, sexuais se entrelaçam ou se justapõem de forma indiscutível.

Ejá que falo em contradições, há, porém, uma premissa da coleção que talvez mereça contraditório: a idéia de um contituatio na história da intolerância que ameniza as rupturas e empalidece contextos históricos específicos. Na apresentação da coleção, as organizadoras não hesitam em dizer que os trabalhos nela incluídos "demonstram que o antijudaísmo em Portugal moderno antecedeu em modernidade o nacional-socialismo alemão por apresentar as características mais globais do anti-semitismo: foi econômico, racial, político e religioso". O livro que melhor traduz essa filosofia, a meu ver, é o de Luiz Nazário, que compara explicitamente os autos-de-fé inquisitoriais com a máquina genocida do nazismo.

Será comparação exata? Muita coisa se poderia dizer em contrário, a começar pelo fato de que, por mais pomposos que fossem os autos-de-fé, menos de $10 \%$ dos processados pela Inquisição ibérica foram relaxados ao braço secular, isto é, queimados (na maioria judaizantes, é verdade), enquanto 6 milhões de judeus foram mortos pelo III Reich alemão nas câmaras de gás ou

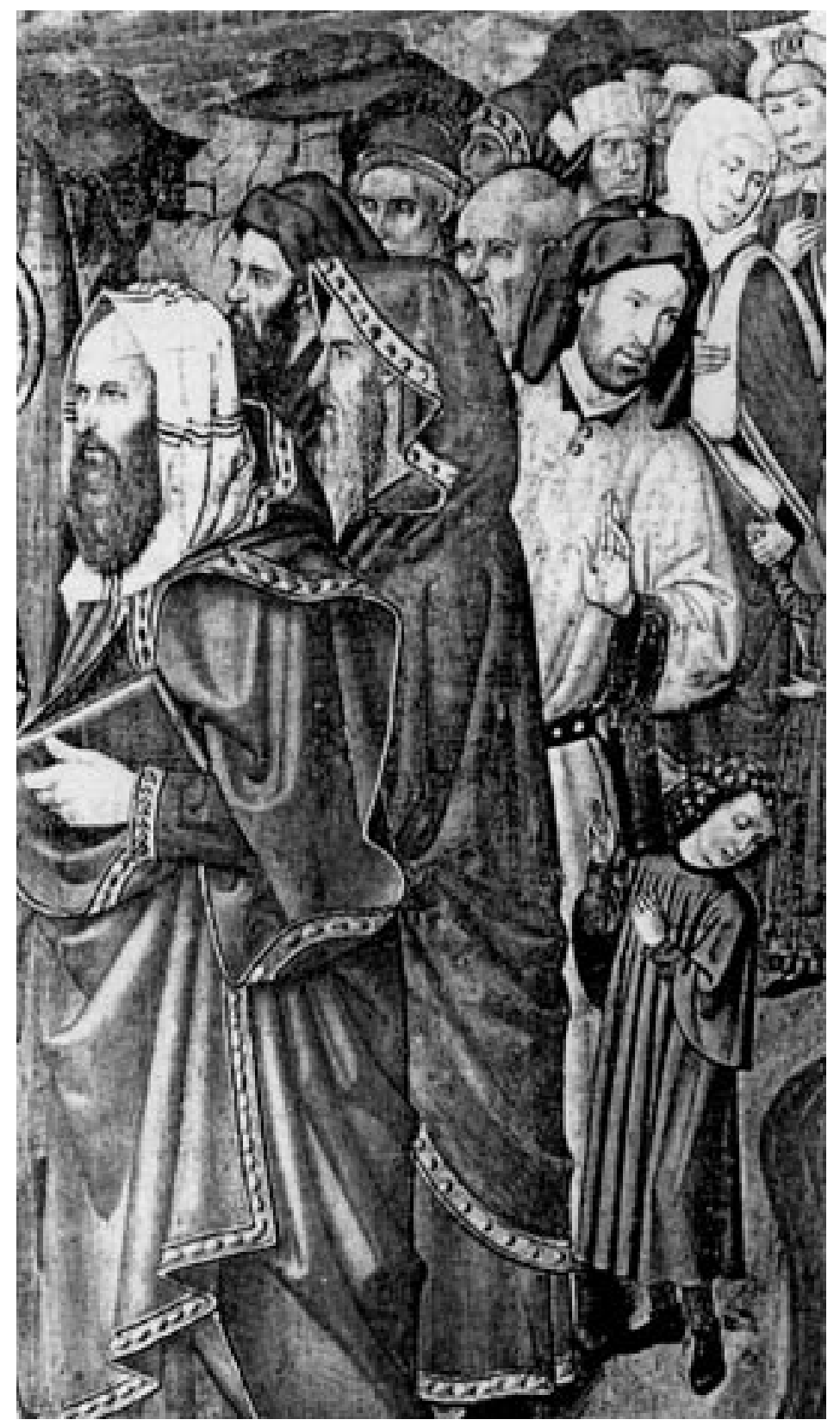

fuzilados. O nazismo arquitetou e executou contra os judeus um projeto genocida, enquanto a Inquisição, arbitrariamente ou não, executou somente uma minoria de cristãosnovos acusados de judaizar em segredo. No caso do nazismo: máquina genocida em escala industrial por razões raciais, ancoradas num racismo biologizante. No caso da Inquisição: execução de centenas e reconciliação de milhares, por razões antes de tudo religiosas, embora, com o tempo, a religião se tenha transformado em mero pretexto para as perseguições. As razões
Detalhe do

Retábulo dos

Esparteros, de

\section{Huguet}


raciais da perseguição inquisitorial, expressas, por exemplo, nos estatutos de pureza de sangue, davam base à inabilitação dos descendentes de judeus - uma lógica do Antigo Regime em terras ibéricas-, ao passo que o estigma racial que o nazismo lançou contra os judeus tinha na inabilitação para cargos públicos a pena mínima, sobretudo depois das Leis de Nuremberg. Seguia-se a expropriação, a internação em guetos infectos ou campos de trabalho, e daí à morte nos lager (campos de extermínio).

Há tantas diferenças entre os tempos inquisitoriais e os tempos do nazismo, que não tenho como evitar minha dúvida sobre se a Inquisição ibérica antecipou, seja lá como for, os métodos e as motivações do nazismo. Em pesquisa que realizei em Berlim, em 1996, juntamente com Ronald Raminelli, estudando os artigos publicados pela Iberoamerikanischer Archiv, entre 1933 e 1945, constatei que a repressão inquisitorial aos cristãos-novos foi tema ausente. Por qual razão os próprios historiadores nazistas ou nazificados não estudaram e celebraram a Inquisição ibérica, sendo tão caros ao III Reich o estigma, a perseguição e o extermínio dos judeus? Para não alongar a polêmica, arriscaria dizer que a ação inquisitorial não dava bom exemplo para o que pretendia fazer o nazismo com os judeus da Europa. Não era caso de convertê-los por coação, mas de exterminá-los com gás venenoso. Não era matéria de religião ou de fé, mas de raça.

Por outro lado, qualquer um que leia o livro fundamental de Bryan Mark Rigg, Os Soldados Judeus de Hitler, publicado pela Imago, em 2003, ficará atônito ao perceber as semelhanças entre os dois contextos, sob vários ângulos. Alemães com remota origem judaica tentando provar sua "pureza de sangue", reinventando mães ou pais, admitindo algumas vezes a avó judia, não tendo como evitar, outras vezes, a confissão de que o pai ou a mãe eram mesmo judeus, embora não praticassem a religião e fossem convertidos. Eram eles os mischlinge - mestiços, em alemão, portadores de nódoa na geração. Processos desse tipo eram examinados pelo próprio Hitler em pessoa - e o foram até 1945 (!). Havia que anexar o retrato do postulante ao processo, a modo de verificar-se se o pleiteante era mais ou menos louro e, sobretudo, como era a morfologia do seu nariz, daí a exigência de um retrato de perfil. O Fuhrer "arianizou" diversos postulantes. Nesse grupo de alemães-judeus que não se sentiam judeus, nem o eram de coração ou de fé, havia mesmo judeus inteiros que, servindo na Wermacht, entre 1939 e 1945, receberam a Cruz de Ferro e outras condecorações militares. Lutavam pelo III Reich por amor à Alemanha ou para proteger parentes da perseguição, ainda que odiando a guerra e sobretudo Hitler.

Se assim é - e foi -, como não comparar os estatutos de limpeza de sangue ibéricos com as diligências que o setor de "pureza racial" do Reich realizava nos anos 1930-40? Aproximo-me, aqui, de Luiz Nazário, não obstante seu demasiado apego ao continuatio, quando afirma que: “[...] a humilhação pública constitui uma técnica de dominação e pressupõe uma íntima cumplicidade entre o poder que a promove e o público que a goza. Diante dessa cumplicidade, as vítimas esperimentam a culpa de existir, num estado de desespero terminal propício à conversão ou ao suicídio".

Suicídio: foi o que fez o judeu italiano e grande escritor Primo Levi, décadas depois de sobreviver ao Holocausto, farto de viver, homem que nunca se sentiu judeu, e foi mesmo estigmatizado pelos judeus poloneses internados em Auschwitz, à espera da morte, porque não sabia falar íidiche. “Que judeu era este?", disse um ashkenazi no barracão do lager, constatando a fragilidade do judaísmo de Levi.

Bastaria essa última polêmica para fundamentar a alta relevância da coleção Histórias da Intolerância que venho de resenhar. Anita Novinsky e Maria Luiza Tucci Carneiro, orientadoras das teses, e todos os autores das obras publicadas, merecem, portanto, o reconhecimeto da comunidade dos historiadores. Pelo que oferecem à historiografia brasileira e pelo espírito de engajamento em causas que realmente valem a pena. Causas nobres. 